\title{
KUALITAS PEMBANGUNAN MANUSIA PULAU NIAS SEBAGAI PERWUJUDAN TUJUAN PEMBANGUNAN MANUSIA BERKELANJUTAN
}

\author{
Rita Herawaty Bangun ${ }^{1}$ \\ Institutional Statistisi BPS Provinsi Sumatera Utara \\ Jalan Asrama No. 179 Medan, Sumatera Utara, 20123 \\ Email: rita.bangun@bps.go.id
}

\begin{abstract}
The purpose of the research is to look at the achievements of human development on Nias Island from its three constituent aspects namely health, education and income. Based on an analysis of the three aspects of the HDI compilers, the quality of human development on Nias Island during the period of 2014 to 2018 showed an increase. This research uses descriptive analysis techniques using secondary data. The results also show that there is still a disparity in human development between regions on Nias Island. The human development of Gunungsitoli City is better compared to other regions. This is influenced by regional factors, infrastructure, and easy access to reach aspects of life such as education facilities and health facilities.To further improve human quality and reduce disparities between regions, the Sumatera Utara Provincial Government needs to make policy programs especially in the aspects of Education and health aspects. Institutional strengthening and infrastructure development to support economic growth for fair and equitable welfare for all people on Nias Island.
\end{abstract}

Keywords: education, healthy, human development, income

\begin{abstract}
Abstrak
Tujuan dari penelitian adalah untuk melihat capaian pembangunan manusia di Pulau Nias dari tiga aspek penyusunnya yaitu aspek kesehatan, aspek pendidikan dan aspek pendapatan. Berdasarkan analisa yang dilakukan terhadap tiga aspek penyusun IPM, kualitas pembangunan manusia di Pulau Nias selama kurun waktu tahun 2014 sampai tahun 2018 menunjukkkan peningkatan. Penelitian ini menggunakan teknik analisis deskriptif dengan menggunakan data sekunder. Hasil penelitian juga menunjukkan masih terdapat disparitas pembangunan manusia antar wilayah di Pulau Nias. Pembangunan manusia Kota Gunungsitoli lebih baik dibandingkan dengan daerah lainnya. Hal ini dipengaruhi oleh faktor wilayah, infrastruktur dan kemudahan akses dalam menjangkau aspek kehidupan seperti fasilitas Pendidikan dan fasilitas kesehatan. Untuk lebih meningkatkan kualitas manusia dan mengurangi disparitas antar wilayah, Pemerintah daerah Provinsi Sumatera Utara perlu membuat program-program kebijakan terutama di aspek Pendidikan dan aspek kesehatan. Penguatan kelembagaan dan pembangunan infrastruktur untuk mendukung pertumbuhan ekonomi untuk kesejahteraan yang adil dan merata bagi semua masyarakat di Pulau Nias.
\end{abstract}

Kata kunci: pembangunan manusia, kesehatan, pendidikan, pendapatan

\section{PENDAHULUAN}

Pembangunan menurut Latuconsina (2017) merupakan rangkaian kegiatan yang dilakukan sebagai upaya untuk mewujudkan keterpaduan dalam pembangunan berbagi sumber daya dalam rangka mencapai tujuan pembangunan berkelanjutan. Pembangunan pada tataran global telah mengacu pada tujuan pembangunan berkelanjutan atau yang lebih populer sebagai Suistable Development Goals (SDGs) sejak tahun 2015. Tujuan Suistable Development Goals (SDGs) antara lain menjamin kehidupan yang sehat, menjamin kualitas pendidikan yang adil dan inklusif, serta peningkatan pertumbuhan ekonomi untuk peningkatan kesejahteraan seluruh umat manusia (BPS, 2019a).

Indeks pembangunan manusia (IPM) mempunyai peranan penting dalam peningkatan kualitas sumber daya manusia. Salah satu faktor penting dalam pertumbuhan ekonomi adalah pembangunan manusia. Menurut Nurwijayanti (2017) penduduk yang berkualitas baik dapat memaksimalkan dan mempunyai kemampuan inovasi dalam mengembangkan faktor-faktor produksi yang ada sehingga akan menggalakkan pertumbuhan ekonomi. 
Pulau Nias merupakan bagian dari wilayah kepulauan yang ada di Provinsi Sumatera Utara terletak di bagian barat Pulau Sumatera dan berada di tengah Samudera Hindia. Pulau Nias terdiri dari lima pemerintahan otonom yaitu Kabupaten Nias, Kabupaten Nias Selatan, Kabupaten Nias Utara, Kabupaten Nias Barat, dan Kota Gunungsitoli. Aksebilitas ke Pulau Nias tergolong sulit karena hanya dapat ditempuh dengan transportasi laut dan udara dengan frekuensi perjalanan yang terbatas. Keberadaan Pulau Nias yang terpisah dari wilayah Provinsi Sumatera Utara sangat berpengaruh terhadap akses pembangunan dan pengembangan sumber daya masyarakat. Kehidupan masyarakat selama ini cenderung terabaikan dan termarjinalkan. Kondisi kehidupan masyarakat di Pulau Nias mengalami berbagai keterbelakangan baik dari aspek ekonomi, pendidikan, kesehatan dan infrastruktur.

Berdasarkan uraian di atas maka perlu dilakukan penelitian tentang pencapain pembangunan manusia beserta perkembangan dimensi penyusun IPM di Pulau Nias. Tujuan dari penelitian ini adalah untuk menganalisis perkembangan IPM dan dimensi penyusunnya yang terdiri dari aspek kesehatan, aspek pendidikan, dan aspek pendapatan selama kurun waktu tahun 2014 - 2018. Hasil dari penelitian diharapkan memberikan gambaran kepada pemerintah daerah Provinsi Sumatera Utara dan pemerintah daerah tentang kualitas pembangunan manusia di Pulau Nias sebagai bentuk implementasi dari tujuan pembangunan berkelanjutan yaitu mencipatakan masyarakat yang sejahtera lahir batin serta melindungi alam.

\section{TINJAUAN PUSTAKA}

Indeks pembangunan manusia (IPM) merupakan indikator capaian pembangunan kualitas hidup masyarakat yang disusun berdasarkan tiga aspek yaitu kesehatan, pendidikan dan pendapatan (BPS, 2019a). Menurut Ilhami (2014) IPM merupakan suatu ukuran kondisi sumber daya manusia pada suatu negara. Indeks pembangunan manusia (IPM) merupakan indeks komposit yang dihitung dari tiga dimensi dasar yaitu umur panjang dan sehat yang diwakili oleh indicator angka harapan hidup saat lahir. Dimensi pengetahuan yang diwakili oleh indikator harapan lama sekolah dan rata-rata lama sekolah sedangkan dimensi standar hidup layak diwakili oleh pengeluaran per kapita yang disesuaikan.

Penelitian tentang IPM sudah banyak dilakukan diantaranya adalah penelitian yang dilakukan Ezkirianto \& Alexandi (2018) yang meneliti hubungan antara pembangunan manusia dan pertumbuhan ekonomi terhadap 33 provinsi di Indonesia. Setiawan \& Hakim (2014) meneliti tentang pengaruh produk domestik bruto, pajak pendapatan, dan desentralisasi pemerintahan terhadap IPM di Indonesia. Pratowo (2013) meneliti tentang factor-faktor yang berpengaruh terhadap indeks pembangunan manusia di Provinsi Jawa Tengah. Arofah \& Rohimah (2019) meneliti tentang pengaruh indikator kesehatan dan pendidikan terhadap pembangunan manusia di Provinsi Nusa Tenggara Timur. Singariya (2014) yang melakukan penelitian tentang determinan pembangunan manusia berdasarkan indikator sosial ekonomi di India. Humaira \& Nugraha (2018) meneliti IPM di Provinsi Barat berdasarkan indikator kesehatan, pendidikan dan pendapatan. Arisman (2018) melakukan penelitian tentang pengaruh jumlah penduduk, inflasi, pengangguran dan pendapatan terhadap IPM di negaranegara Asean.

\section{METODE PENELITIAN}

Penelitian ini merupakan penelitian deskriptif. Penelitian deskriptif adalah penelitian yang dirancang untuk mendeskripsikan fenomena-fenomena yang ada dan dalam penelitian deskriptif tidak ada pengujian hipotesis seperti pada peneltian eksperimen (Linarwati, Fathoni, \& Minarish, 2016). Nasution (2017) menyatakan bahwa peneltian deskriptif berfungsi menerangkan keadaan, gejala atau persoalan yang terjadi dalam masyarakat atau lingkungan. Data yang digunakan merupakan data sekunder yang bersumber dari publikasi yang diterbitkan oleh Badan Pusat Statistik (BPS) dan instansi terkait dengan pembangunan manusia. Kriteria penghitungan IPM berdasarkan tiga aspek penyusunnya menurut BPS (2019) dapat dikelompokkan menjadi empat kategori yang ditampilkan pada Tabel 1. 
Tabel 1. Kriteria Pengelompokan IPM

\begin{tabular}{cc}
\hline Kriteria IPM & Nilai \\
\hline Sangat tinggi & IPM $\geq 80$ \\
Tinggi & $70 \leq I P M<80$ \\
Sedang & $60 \leq I P M<70$ \\
Rendah & IPM $<60$ \\
\hline
\end{tabular}

Sumber: BPS Provinsi Sumatera Utara, 2019

\section{HASIL DAN PEMBAHASAN}

\section{Perkembangan Pembangunan Manusia Pulau Nias}

Kualitas pembangunan manusia merupakan isu strategis yang capauannya perlu dipantau. Capaian pembangunan manusia menurut kabupaten/kota disajikan secara lengkap pada Gambar 1. Berdasarkan Gambar 1, pencapaian pembangunan manusia di Pulau Nias lebih rendah dibandingkan dengan kabupaten kota lainnya di Provinsi Sumatera Utara. Pencapaian pembangunan manusia di wilayah kabupaten kota di Pulau Nias berada di kisaran 60 poin. Indeks pembangunan manusia (IPM) tertinggi berhasil dicapai Kota Medan yaitu 80,65 point, artinya kualitas pembangunan manusia berada pada kategori tinggi. Sebagai ibukota provinsi, Kota Medan merupakan pusat dari seluruh kegiatan baik perekonomian, kesehatan dan pendidikan yang mendukung Kota Medan dalam pencapaian pembangunan manusia yang berkualitas. Secara umum, status pembangunan manusia di Pulau Nias masih berada pada kategori sedang.

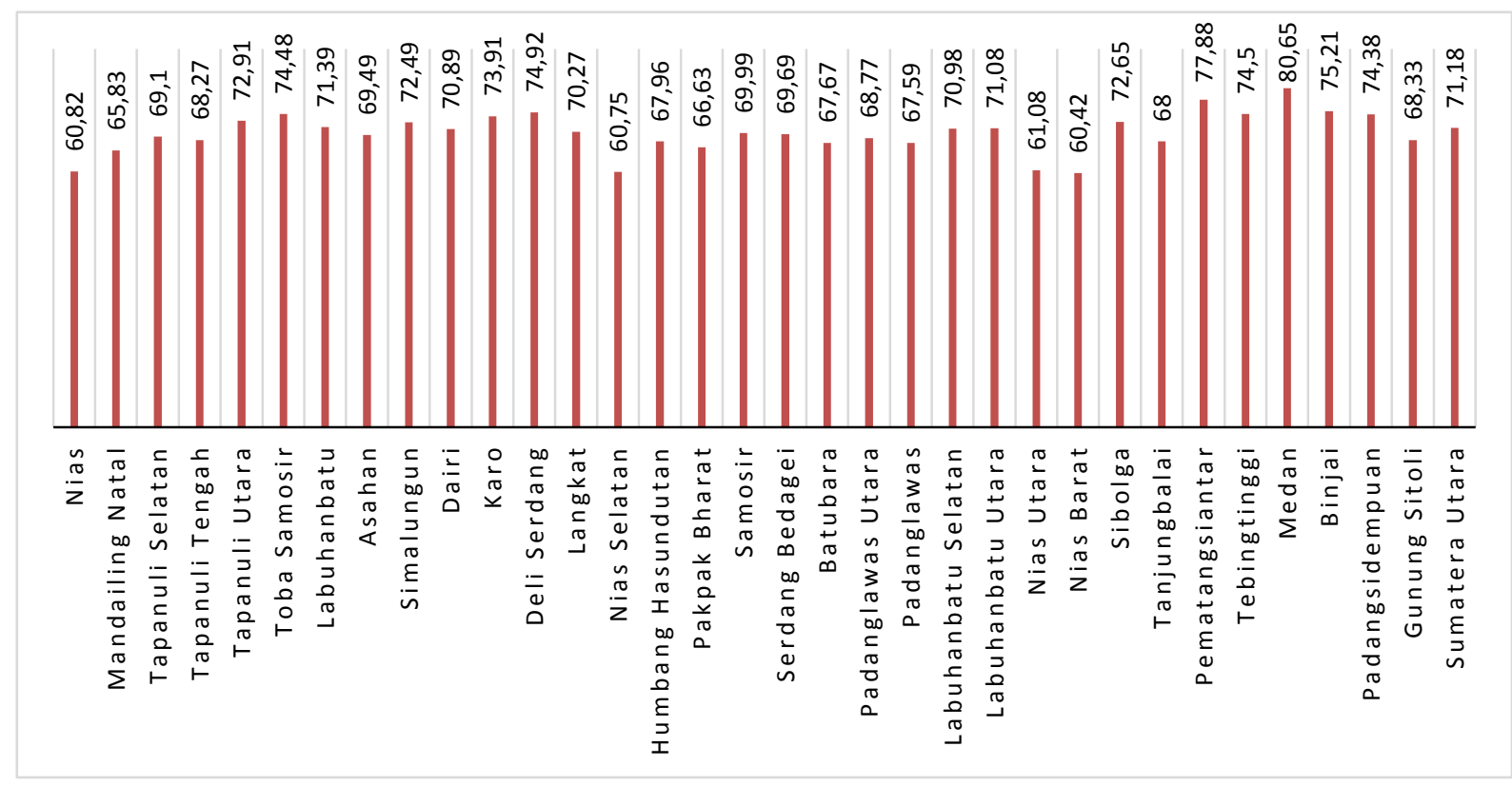

Gambar 1. Indeks Pembangunan Manusia Kabupaten/Kota di Provinsi Sumatera Utara Tahun 2018 Sumber: BPS Provinsi Sumatera Utara, 2019

Disparitas pembangunan manusia dapat dipengaruhi oleh beberapa faktor diantaranya adalah geografis wilayah dan ketersediaan fasilitas dasar. Menurut Amrillah \& Yasa (2013) ketimpangan yang terjadi antar daerah disebabkan perbedaan komposisi jumlah penduduk, sumber daya dan karakteristik daerah. Evianto (2010) dalam penelitiannya tentang analisis disparitas indeks pembangunan manusia di Provinsi Jawa Barat menyatakan bahwa ketimpangan yang terjadi diakibatkan tipologi daerah, daerah perkotaan cenderung memiliki IPM yang tinggi karena kemudahan mengakses fasilitas dasar. Menurut Pradnyadewi \& Purbadharmaja (2017) disparitas pembangunan yang terjadi dapat diatasi dengan cara melakukan pemerataan pembangunan infrastruktur, meningkatkan perekonomian berdasarkan potensi sumber daya yang dimiliki suatu daerah dan meningkatkan kualitas sumber daya manusia. 
Pembangunan manusia di Pulau Nias secara umum semakin baik dan terus menunjukkan peningkatan selama lima tahun terakhir, Indeks pembangunan manusia (IPM) Kabupaten Nias mencapai 60,82, IPM Kabupaten Nias Selatan mencapai 60,75, IPM Kabupaten Nias Utara sebesar 61,08 point, IPM Kabupaten Nias Barat sebesar 60,42, dan IPM Kota Gunungsitoli mencapai 68,33 point pada tahun 2018 (BPS, 2019b). Kabupaten Nias Selatan dan Nias Barat menunjukkan peningkatan kualitas manusia yang lebih baik dibandingkan pencapaian di tahun 2017. Kualitas pembangunan manusia di kedua kabupaten ini berhasil mencapai kategori sedang di Tahun 2018. Indeks pembangunan manusia (IPM) di Kabupaten Nias Selatan mencapai angka 60,75 sedangkan IPM Kabupaten Nias Barat mencapai angka 60,42. Keberhasilan pencapaian pembangunan manusia di kedua kabupaten tersebut didukung oleh kerjasama yang sinergis antara pemerintah daerah dan masyarakat. Tomuka (2013) berpendapat bahwa penerapan good governance merupakan kebutuhan mutlak demi terciptanya peningkatan kesejahteraan rakyat.

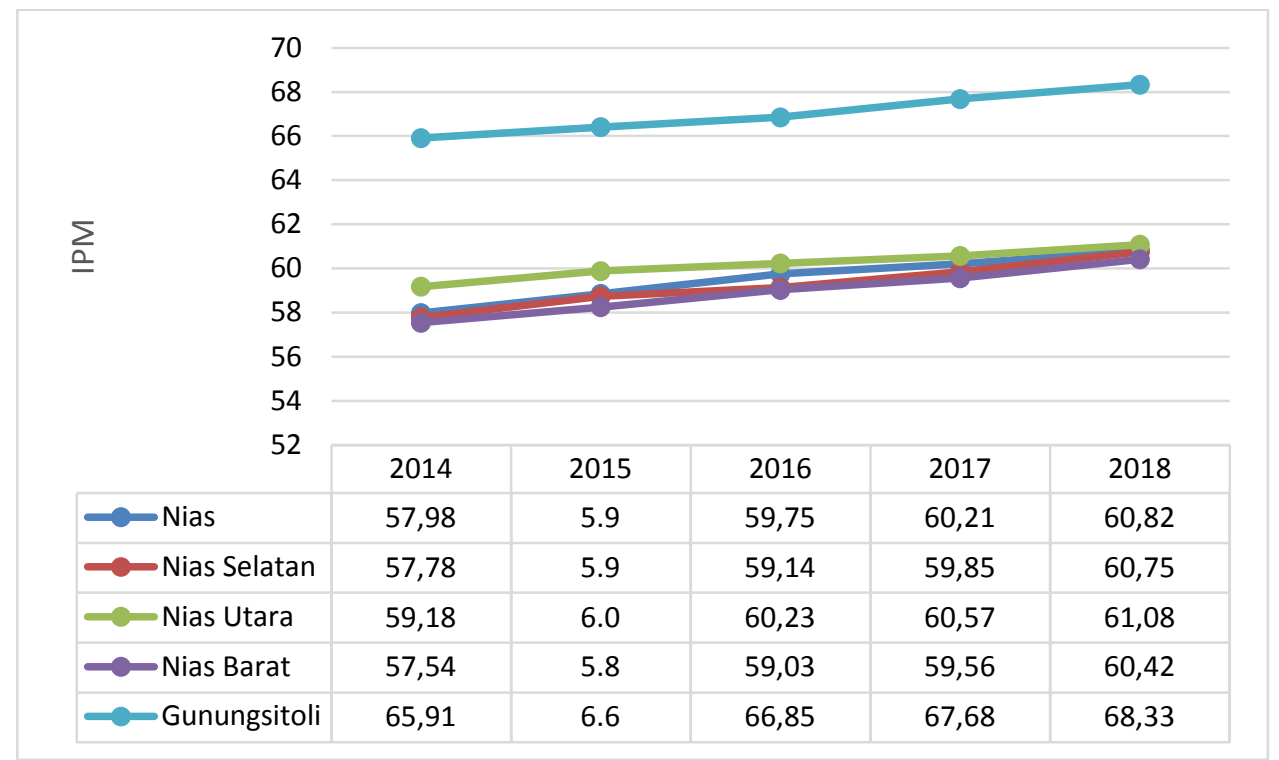

Gambar 2. Perkembangan IPM Pulau Nias Tahun 2014-2018

Sumber: BPS Provinsi Sumatera Utara, 2019

\section{Masyarakat Pulau Nias Semakin Sehat}

Angka harapan hidup (AHH) merupakan indicator yang mewakili aspek kesehatan dalam penghitungan IPM. Menurut Bangun (2019) angka harapan hidup saat lahir merupakan indikator yang digunakan untuk mengukur derajat kesehatan suatu wilayah baik dari sarana, akses, dan kualitas kesehatan. Secara tidak langsung, peningkatan umur harapan hidup menunjukkan derajat kesehatan masyarakat yang semakin baik dalam semua aspek kesehatan. Ardianti et al. (2015) menyatakan bahwa derajat kesehatan masyarakat dapat dijadikan salah satu alat untuk mengevaluasi kinerja pemerintah pada keberhasilan pembangunan kesehatan serta sosial eknomi di suatu wilayah. Penelitian yang dilakukan Nurkuntari et al., (2016) menyimpulkan bahwa angka harapan hidup berhubungan erat dengan IPM di Provinsi Jawa Barat.

Angka harapan hidup Pulau Nias selama lima tahun terakhir menunjukkan perbaikan. Angka harapan hidup Kabupaten Nias pada tahun 2018 sebesar 69,43 tahun, artinya bayi yang lahir di Kabupaten Nias pada tahun 2018 diharapkan dapat bertahan hidup sampai usia 68 sampai 70 tahun. Kota Gunung Sitoli memiliki angka harapan hidup yang lebih baik dibandingkan dengan daerah kabupaten yang lain. Angka harapan hidup Kota Gunungsitoli sebesar 70,67 tahun artinya bayi yang lahir pada tahun 2018 di Kota Gunungsitoli diharapkan hidup sampai usia 70 sampai 80 tahun. Kabupaten Nias Selatan memiliki angka harapan hidup yang paling rendah yaitu 68, 22 tahun. Angka harapan hidup dapat dipengaruhi oleh beberapa faktor diantaranya faktor sosial ekonomi, pendidikan dan kesehatan. Sugiantari \& Budiantara (2013) berpendapat bahwa penurunan angka kematian bayi, pemberian ASI kepada bayi yang berusia 0-11 bulan dan pemberian imunisasi kepada balita dapat meningkatkan angka harapan hidup. Selain itu, peningkatan kesejahteraan sosial ekonomi dan 
perbaikan kesehatan melalui penambahan anggaran alokasi kesehatan juga meningkatkan angka harapan hidup (Danasari \& Wibowo, 2018; U. Sari, et al., 2016). Salah satu cara meningkatkan angka harapan hidup dengan menekan angka kematian bayi dan perbaikan status gizi masyarakat (Anggraini \& Lisyaningsih, 2010). Zuhairoh \& Melaniani (2018) juga menyimpulkan bahwa penurunan angka kematian bayi dapat meningkatkan IPM.

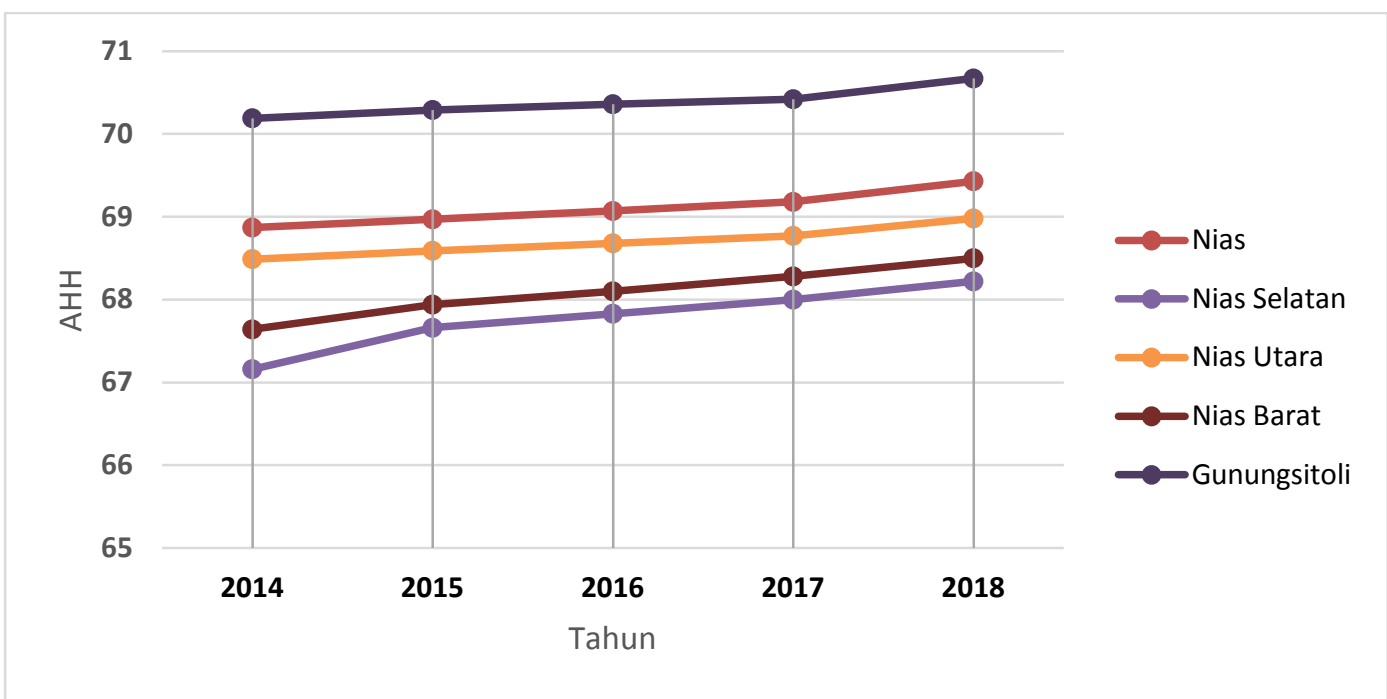

Gambar 3. Perkembangan Angka Harapan Hidup Pulau Nias Tahun 2014-2018 Sumber: BPS Provinsi Sumatera Utara, 2019

\section{Masyarakat Pulau Nias Semakin Berpengetahuan}

Angka harapan lama sekolah dan rata-rata lama sekolah merupakan indikator dari aspek pendidikan. Harapan lama sekolah menghitung pendidikan dari usia 7 tahun ke atas, sedangkan rata-rata lama sekolah menghitung dari usia 25 tahun ke atas (BPS, 2019b). Seran (2017) menyatakan bahwa pendidikan merupakan salah satu cara untuk meningkatkan kualitas sumber daya manusia. Peningkatan kualitas hidup masyarakat dengan menyediakan sekolah yang baik dan mendorong masyarakat untuk mengenyam pendidikan setinggitingginya (Meydiasari \& Soejoto, 2017).

Pencapaian Pulau Nias di aspek pendidikan semakin membaik dilihat dari indikator angka harapan lama sekolah dan rata-rata lama sekolah selama lima tahun terakhir. Harapan lama sekolah anak-anak berusia 7 tahun di Pulau Nias berkisar antara 12 tahun sampai 14 tahun pada tahun 2018. Harapan lama sekolah penduduk Kota Gunungsitoli mencapai 13,71 tahun, artinya anak-anak yang berusia 7 tahun diharapkan mampu menempuh pendidikan sampai tingkat Diploma. Pencapaian harapan lama sekolah Kota Gunungsitoli lebih tinggi dibandingkan harapan lama sekolah Provinsi Sumatera Utara pada tahun 2018 yaitu 13,14 tahun. 


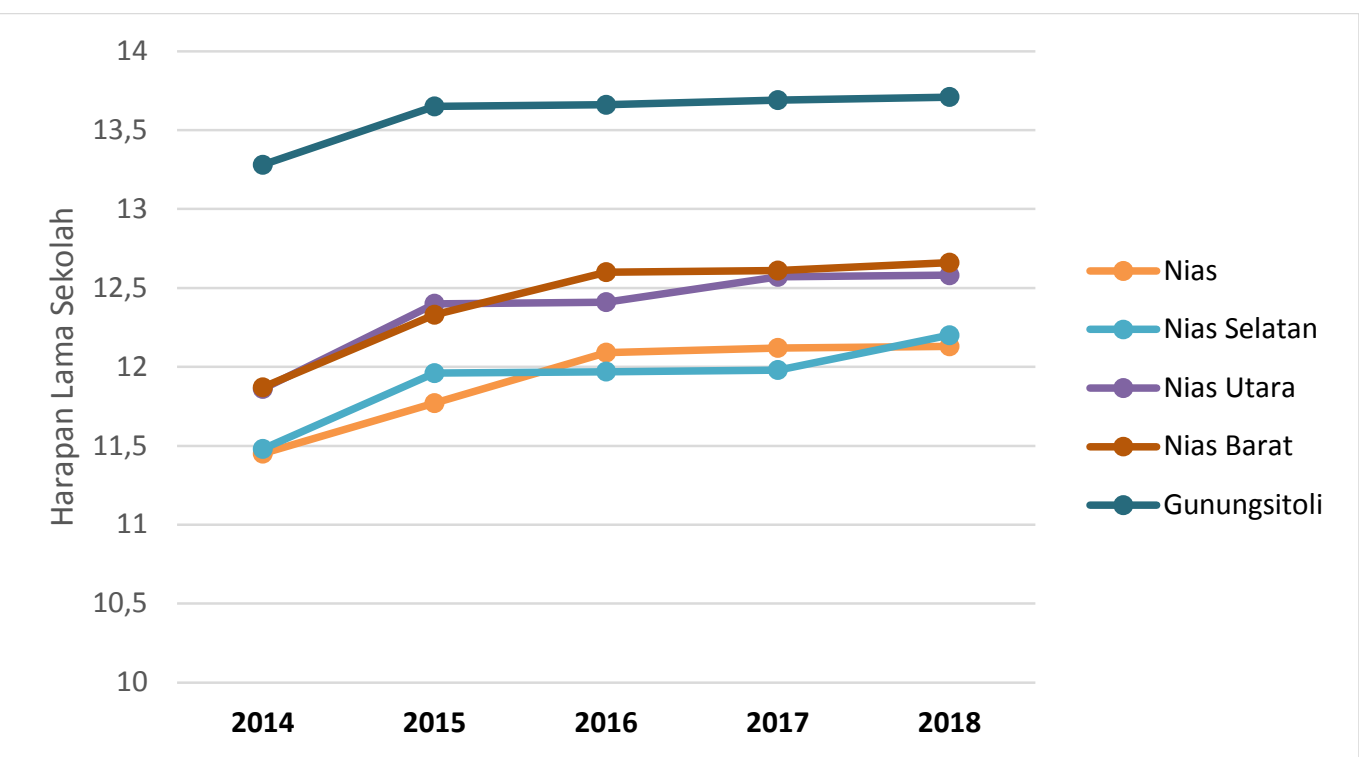

Gambar 4. Perkembangan Angka Harapan Lama Sekolah Pulau Nias Tahun 2014-2018 Sumber: BPS Provinsi Sumatera Utara, 2019

Rata-rata lama sekolah penduduk di Pulau Nias juga mengalami peningkatan. Masyarakat yang tinggal di Pulau Nias yang usianya 25 tahun ke atas rata-rata telah mendapatkan pendidikan antara 4 sampai 9 tahun. Pencapaian aspek pendidikan Kabupaten Nias lebih rendah dibandingkan daerah lainnya sedangkan Kota Gunungsitoli lebih tinggi dibandingkan daerah lainnya. Menurut Berlian VA (2011) rendahnya pencapaian aspek pendidikan dipengaruhi oleh beberapa faktor yaitu kemiskinan, dukungan pemerintah daerah yang masih rendah serta sarana dan prasarana fasilitas pendidikan yang masih kurang memadai. Kahar (2018) juga menjelaskan bahwa tersedianya fasilitas pendidikan yang memadai khususnya pada daerah terpencil akan meningkatkan angka harapan lama sekolah. . Muda et al., (2019) menyatakan bahwa pengembangan sumber daya manusia dapt dilakukan dengan perbaikan modal manusia. Salah satu cara untuk peningkatan aspek pendidikan adalah dengan penambahan alokasi anggaran pendidikan khususnya pada daerah yang memiliki anggaran fiskal yang rendah (Aquariansyah, 2018; Berlian VA, 2011; Ilhami, 2014; Lengkong, Rotinsulu, \& Walewangko, 2017).

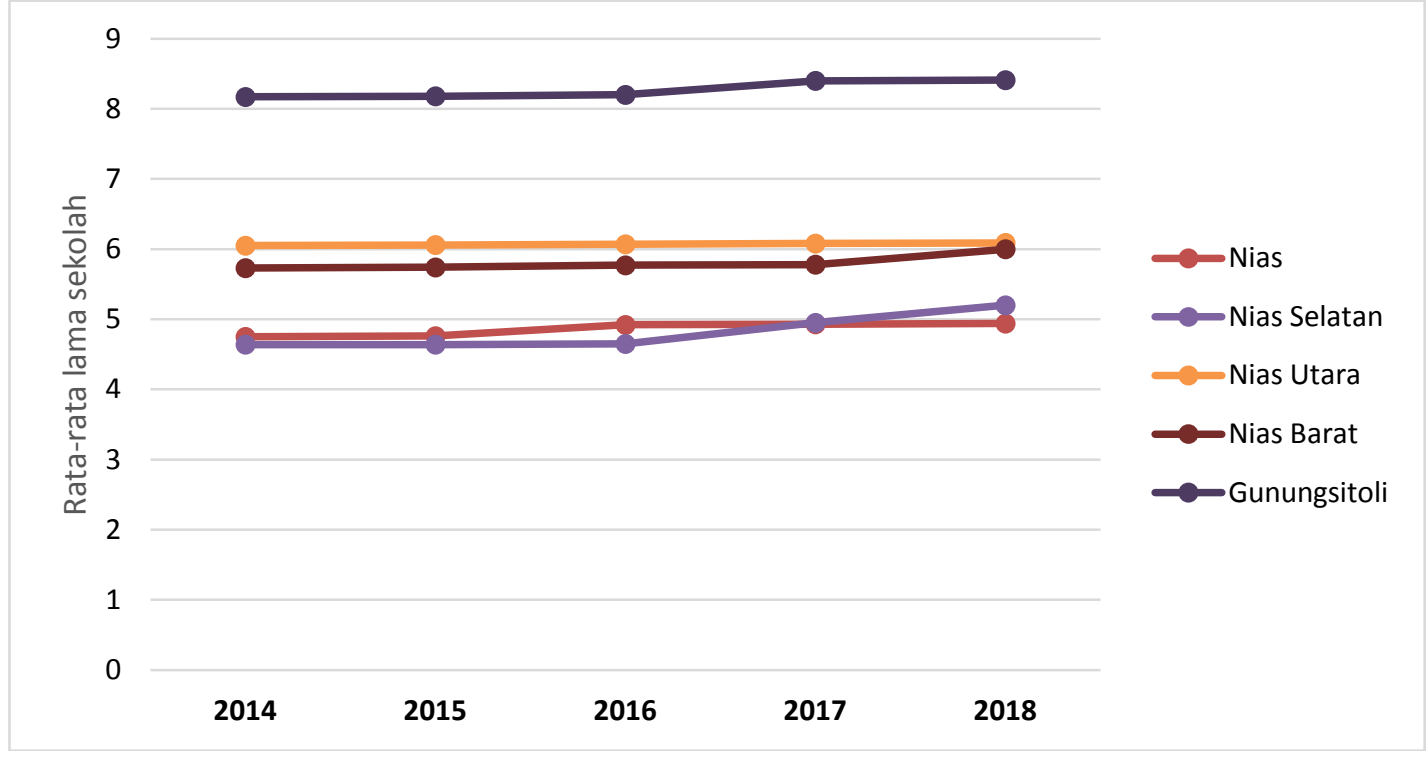

Gambar 5. Perkembangan Angka Rata-rata Lama Sekolah Pulau Nias Tahun 2014-2018 Sumber: BPS Provinsi Sumatera Utara, 2019 


\section{Masyarakat Pulau Nias Semakin Sejahtera}

Aspek hidup layak diukur oleh indikator pengeluaran per kapita yang disesuaikan. Jusherni (2013) berpendapat bahwa daya beli masyarakat mencerminkan kemampuan masyarakat dalam membelanjakan uangnya dalam bentuk barang dan jasa.

Masyarakat Pulau Nias semakin sejahtera selama lima tahun terakhir. Hal ini dapat dilihat dari pengeluaran per kapita masyarakat yang meningkat setiap tahunnya.. Perbandingan antar wilayah di Pulau Nias, masyarakat Kota Gunungsitoli memiliki pengeluaran yang lebih tinggi dibandingkan dengan daerah lainnya sedangkan Kabupaten Nias Barat memiliki tingkat pengeluaran yang paling rendah. Menurut Latifah \& Darsyah (2017) bahwa besar kecilnya pengeluaran rata-rata per kapita merupakan indikator kesejahteraan masyarakat yang dipengaruhi oleh pendapatan, pendidikan, kebiasaan dan kebutuhan masyarakat. Mirza (2012) menyimpulkan bahwa peningkatan pertumbuhan ekonomi akan merubah pola konsumsi masyarakat khususnya daya beli masyarakat, tingginya daya beli masyarakat akan meningkatkan IPM sehingga dapat disimpulkan bahwa semakin tinggi pertumbuhan ekonomi maka IPM akan meningkat. Juliarini (2019) dalam penelitiannya juga menyimpulkan bahwa pendapatan daerah mempengaruhi pembangunan manusia.

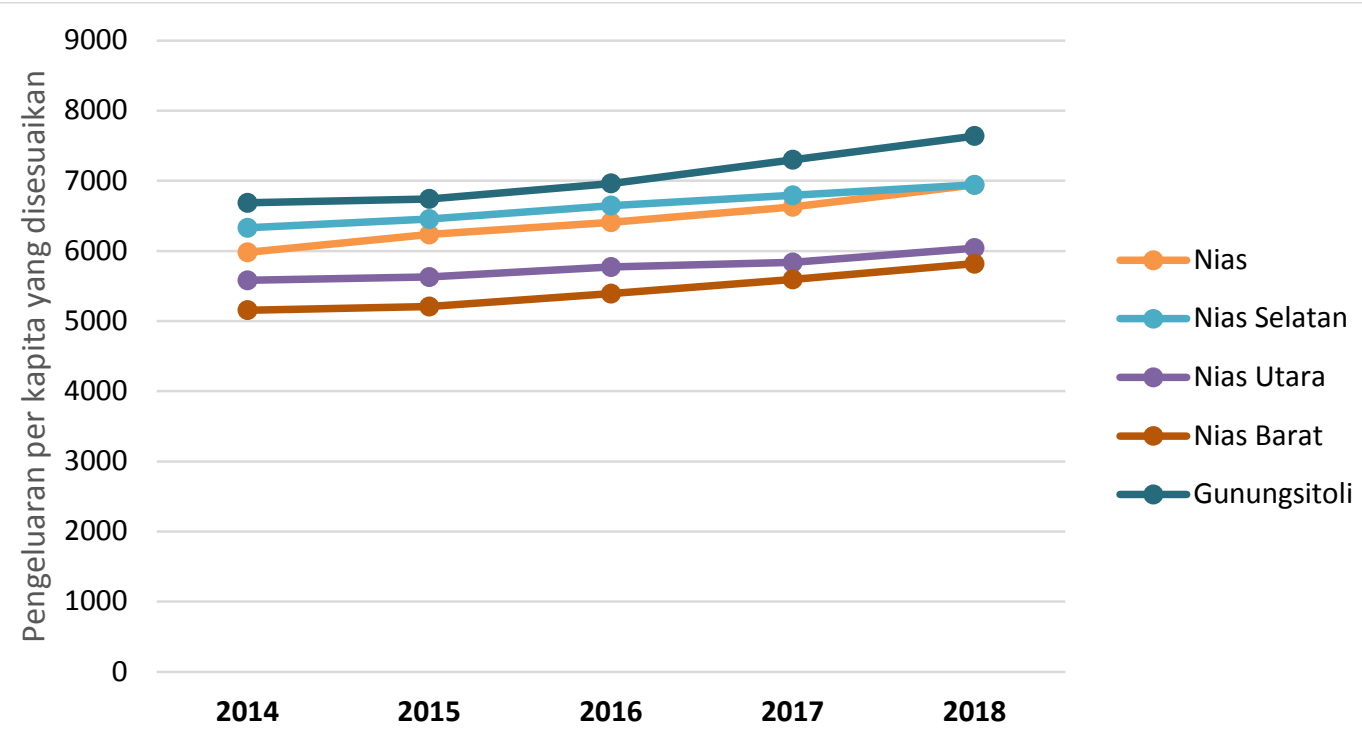

Gambar 6. Perkembangan Pengeluaran Per Kapita Yang Disesuaikan Pulau Nias Tahun 2014-2018 Sumber: BPS Provinsi Sumatera Utara, 2019

\section{SIMPULAN DAN SARAN}

Penelitian ini bertujuan untuk melihat capaian pembangunan manusia di Pulau Nias dari tiga aspek penyusunnya yaitu aspek kesehatan, aspek pendidikan dan aspek pendapatan. Berdasarkan analisa yang dilakukan terhadap tiga aspek penyusun IPM, kualitas pembangunan manusia di Pulau Nias selama kurun waktu tahun 2014 sampai tahun 2018 menunjukkkan peningkatan. Hasil penelitian juga menunjukkan masih terdapat disparitas pembangunan manusia antar wilayah di Pulau Nias. Pembangunan manusia Kota Gunungsitoli lebih baik dibandingkan dengan daerah lainnya. Hal ini dipengaruhi oleh faktor wilayah, infrastruktur dan kemudahan akses dalam menjangkau aspek kehidupan seperti fasilitas Pendidikan dan fasilitas kesehatan. Untuk lebih meningkatkan kualitas manusia dan mengurangi disparitas antar wilayah, Pemerintah daerah Provinsi Sumatera Utara perlu membuat program-program kebijakan terutama di aspek Pendidikan dan aspek kesehatan. Penguatan kelembagaan dan pembangunan infrastruktur untuk mendukung pertumbuhan ekonomi untuk kesejahteraan yang adil dan merata bagi semua masyarakat di Pulau Nias.

\section{DAFTAR PUSTAKA}

Amrillah, \& Yasa, I. N. M. (2013). Analisis Disparitas Pendapatan Per Kapita Antar Kecamatan dan Potensi Pertumbuhan Ekonomi Kecamatan di Kabupaten Karangasem. Jurnal Ekonomi Pembangunan Universitas Udayana, 2(4), 181189. 
Anggraini, E., \& Lisyaningsih, U. (2010). Disparitas Spasial Angka Harapan Hidup Di Indonesia Tahun 2010. Jurnal Bumi Indonesia, 2(3), 71-80.

Aquariansyah, F. (2018). Analisis Pengaruh Belanja Pemerintah Bidang Pendidikan Dan Kesehatan Terhadap Indeks Pembangunan Manusia Di Kota Bandar Lampung Tahun 2010-2016 Dalam Persepektif Ekonomi Islam. Universitas Islam Negeri Raden Intan.

Ardianti, A. V., Wibisono, S., \& Jumiati, A. (2015). Faktor-Faktor Yang Mempengaruhi Angka Harapan Hidup Di Kabupaten Jember ( The Factors That Affect Life Expectancy In District Of Jember ). Artikel IImiah Mahasiswa, 2(1), 1-6.

Arisman, A. (2018). Determinant Of Human Development Index In Asean Countries. Signifikan: Jurnal IImu Ekonomi, 7(1), 113-122.

Arofah, I., \& Rohimah, S. (2019). Analisis Jalur Untuk Pengaruh Angka Harapan Hidup, Harapan Lama Sekolah, Rata-Rata Lama Sekolah Terhadap Indeks Pembangunan Manusia Melalui Pengeluaran Per Kapita Di Provinsi Nusa Tenggara Timur. Jurnal Saintika Unpam, 2(1), 76-87.

Bangun, R. H. (2019). Analisis Determinan Angka Harapan Hidup Kabupaten Mandailing Natal. Jurnal Akutansi \& Ekonomi, $4(3), 22-31$.

Berlian Va, N. (2011). Faktor-Faktor Yang Terkait Dengan Rendahnya Pencapaian Wajib Belajar Pendidikan Dasar 9 Tahun. Jurnal Pendidikan Dan Kebudayaan, 17(1), 43-57.

BPS. (2019a). Indeks Pembangunan Manusia 2018. Jakarta: Badan Pusat Statistik.

BPS. (2019b). Indeks Pembangunan Manusia Provinsi Sumatera Utara 2018. Medan: Badan Pusat Statistik Provinsi Sumatera Utara

Danasari, L. S., \& Wibowo, A. (2018). Analisis Angka Harapan Hidup Di Jawa Timur Tahun 2015. Jurnal Biometrika Dan Kependudukan, 6(1), 17-25.

Evianto, E. (2010). Analisis Disparitas Indeks Pembangunan Manusia Kabupaten / Kota Di Provinsi Jawa Barat Indeks Pembangunan Manusia Kabupaten/Kota Di Provinsi Jawa Barat Dan Faktor-Faktor Yang Mempengaruhi Capaiannya. Universitas Indonesia.

Ezkirianto, R., \& Alexandi, M. F. (2018). Analisis Keterkaitan Antara Indeks Pembangunan Manusia Dan Pdrb Per Kapita Di Indonesia. Jurnal Ekonomi Dan Kebijakan Pembangunan, 2(1), 14-29.

Humaira, U. H., \& Nugraha, J. (2018). Analysis Of Factors Affecting The Human Development Index In West Kalimantan Province Using Data Panel Data Regression. Jurnal Eksakta, 18(2), 97-105.

Ilhami, S. (2014). Analisis Pengaruh Anggaran Pendidikan Terhadap Indeks Pembangunan Manusia Di Indonesia. Institur Pertanian Bogor.

Juliarini, A. (2019). Kinerja Pendapatan Daerah Terhadap Indeks Pembangunan Manusia Studi Kasus Provinsi Di Pulau Jawa. Simposium Nasional Keuangan Negara, 15(1), 934-957.

Jusherni. (2013). Analisis Segmentasi Gaya Hidup Pada Mahasiswa Jurusan Manajemen S1 Fakultas Ekonomi Universitas Riau. Journal Of Chemical Information And Modeling, 21(1), 1-17.

Kahar, A. M. (2018). Analisis Angka Harapan Lama Sekolah Di Indonesia Timur Menggunakan Weighted Least Squares Regression. Jurnal Matematika "Mantik," 4(1), 32-41.

Latifah, N., \& Darsyah, M. (2017). Analisis Faktor Yang Mempengaruhi Pengeluaran Per Kapita Provinsi Yogyakarta Dengan Pendekatan Regresi Linier Sederhana. Seminar Nasional Pendidikan, Sains Dan Teknologi Fakultas Matematika Dan IImu Pengetahuan Alam Universitas Muhammadiyah Semarang, 206-208.

Latuconsina, Z. M. Y. (2017). Analisis Faktor-Faktor Yang Mempengaruhi Indeks Pembangunan Manusia Kabupaten Malang Berbasis Pendekatan Perwilayahan Dan Regresi Panel. Journal Of Regional And Rural Development 
Planning, 1(2), 202-216.

Lengkong, S. M. K., Rotinsulu, D. C., \& Walewangko, E. N. (2017). Pengaruh Alokasi Anggaran Pendidikan Dan Kesehatan Terhadap Indeks Pembangunan Manusia Dan Dampaknya Terhadap Pertumbuhan Ekonomi Kota Bitung. Jurnal Pembangunan Ekonomi Dan Keuangan Daerah, 19(2), 1-20.

Linarwati, M., Fathoni, A., \& Minarish, M. M. (2016). Studi Deskriptif Pelatihan Dan Pengembangan Sumberdaya Manusia Serta Penggunaan Metode Behavioral Event Interview Dalam Merekrut Karyawan Baru Di Bank Mega Cabang Kudus. Journal Of Management, 2(2), 1-8.

Meydiasari, D. A., \& Soejoto, A. (2017). Analisis Pengaruh Distribusi Pendapatan, Tingkat Pengangguran, Dan Pengeluaran Pemerintah Sektor Pendidikan Terhadap IPM Di Indonesia. Jurnal Pendidikan Ekonomi Manajemen Dan Keuangan, 01(02), 116-126.

Mirza, D. S. (2012). Pengaruh Kemiskinan,Pertumbuhan Ekonomi,Belanja Modal Terhadap Indeks Pembangunan Manusia Di Jawa Tengah Tahun 2006-2009. Economic Development Analysis Journal, 1(1), 1-15.

Muda, R., Koleangan, R., \& Kalangi, J. B. (2019). Pengaruh Angka Harapan Hidup, Tingkat Pendidikan, Dan Pengeluaran Terhadap Pertumbuhan Ekonomi Di Sulawesi Utara Pada Tahun 2003-2007. Jurnal Berkala IImiah Efisiensi, 19(01), 44-55.

Nasution, L. M. (2017). Statistik Deskriptif. Jurnal Hikmah, 14(1), 49-55.

Nurkuntari, Y., Fauzi, F., \& Darsyah, M. Y. (2016). Analisis Jalur Terhadap Faktor-Faktor Yang Mempengaruhi Indeks Pembangunan Manusia. Majalah Ekonomi Dan Bisnis, 12(2), 101-108.

Nurwijayanti, N. (2017). Pengaruh Indikator Komposit Pembangunan Manusia Terhadap Pertumbuhan Ekonomi Kabupaten/Kota Di Provinsi Daerah Istimewa Yogyakarta Tahun 2004-2013. Jurnal Pendidkan Dan Ekonomi, 6(6), 520-529.

Pradnyadewi, D., \& Purbadharmaja, I. B. (2017). Pengaruh Ipm, Biaya Infrastruktur, Investasi Dan Pertumbuhan Ekonomi Terhadap Ketimpangan Distribusi Pendapatan Di Provinsi Bali. E-Jurnal Ep Unud, 6(2), 255-285.

Pratowo, N. I. (2013). Analisis Faktor-Faktor Yang Berpengaruh Terhadap Indeks Pembangunan Manusia. Jurnal Studi Ekonomi Indonesia, 1(1), 15-31.

Sari, U., Harianto, H., \& Falatehan, A. F. (2016). Strategi Meningkatkan Angka Harapan Hidup (Ahh) Melalui Alokasi Anggaran Kesehatan Di Provinsi Jawa Barat. Jurnal Manajemen Pembangunan Daerah, 8(1), $29-41$.

Seran, S. (2017). Hubungan Antara Pendidikan, Kemiskikan Dan Pertumbuhan Ekonomi Dengan Kemiskinan. Jurnal Ekonomi Kuantitatif Terapan, 10(1), 59-71.

Setiawan, M. B., \& Hakim, A. (2014). Indeks Pembangunan Manusia Indonesia. Jurnal Economia, 9(1), 18-26.

Singariya, M. (2014). Socioeconomic Determinants Of Human Development Index In India. Management And Administrative Sciences Review, 3(1), 69-84.

Sugiantari, A. P., \& Budiantara, I. N. (2013). Analisis Faktor-Faktor Yang Mempengaruhi Angka Harapan Hidup Di Jawa Timur Menggunakan Regresi Semiparametrik Spline. Jurnal Sains Dan Seni Its, 2(1), 37-41.

Tomuka, S. (2013). Penerapan Prinsip-Prinsip Good Governance Dalam Pelayanan Publik Di Kecamatan Girian Kota Bitung (Studi Tentang Pelayanan Akte Jual Beli). Politico: Jurnal IImu Politik, 1(3), 1-15.

Zuhairoh, Z. A., \& Melaniani, S. (2018). Pengaruh Angka Kematian Bayi, Angka Partisipasi Murni, Rasio Ketergantungan Terhadap Indeks Pembangunan Manusia Di Provinsi Jawa Timur. Jurnal Biometrika Dan Kependudukan, 7(1), 8795. 